\title{
Mass balance and changes of surface slope, crevasse and flow pattern of Erikbreen, northern Spitsbergen: an application of a geographical information system (GIS)
}

\author{
BERND ETZELMÜLLER, GEIR VATNE, RUNE S. ØDEGÅRD and JOHAN LUDVIG SOLLID
}

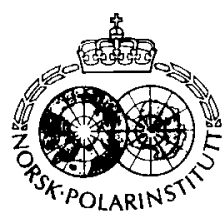

\begin{abstract}
Etzelmüller, B., Vatne, G.. Ødegård, R. \& Sollid, J. L. 1993: Mass balance and change of surface slope, crevasse and flow pattern of Erikbreen, northern Spitsbergen: an application of a geographical information system (GIS). Polar Research 12(2), 131-146

The polythermal valley glacier Erikbreen $\left(79^{\circ} 40^{\prime} \mathrm{N} 12^{\circ} 30^{\prime} \mathrm{E}\right)$, northern Spitsbergen, was investigated in 1970 and 1990 using digital photogrammetry and digital elevation model (DEM) techniques. The bottom topography was derived from radio-echo soundings. Based on the DEM, mass balance and changes of surface slope, crevasse and flow pattern were evaluated, and internal ice deformation velocities were calculated. Calculations of the total mass balance show that Erikbreen has not been in equilibrium for the last 20 ycars. The average surface lowering was $0.38 \mathrm{~m} / \mathrm{a}$ and the volume had decreased by $5 \%$ to $6 \%$ from 1970 to 1990 or on the average by $3.5 \times 10^{6} \mathrm{~m}^{3} \mathrm{a}^{-1}$ water. The glacier surface subsided over the whole glacier area except in minor areas with northfacing slopes in the accumulation area. The surface slope and the crevasse pattern, however, did not change significantly during the 20-year-period, except in areas below $100 \mathrm{~m}$ a.s.l.
\end{abstract}

Bernd Etzelmüller, Geir Vatne, Rune S. Ødegdrd \& Johan Ludvig Sollid. Department of Geography, University of Oslo, P.O. Box 1042, N-0316 Oslo, Norway.

\section{Introduction}

In the summers of 1990,1991 and 1992 a glaciological and hydrological monitoring program was established on the polythermal valley glacier Erikbreen $\left(79^{\circ} 40^{\prime} \mathrm{N}, 12^{\circ} 30^{\prime} \mathrm{E}\right.$, Fig. 1) in the Liefdefjord area, Svalbard (B $\varnothing$ 1992; Vatne et al. 1992; Ødegård et al. 1992; Etzelmüller et al. 1993; Sollid et al. in press). The main aim of this work was to study the erosion, entrainment, transport and sedimentation processes within a highly glaciated arctic drainage basin. This paper deals with further studies of the mass balance and the glacier dynamics as an input to investigations of the glacial material transport, the glacier front sedimentation processes and the subglacial drainage.

Vertical aerial photographs from 1970 and 1990 of the Liefdefjord region were used for digital photogrammetric mapping of changes in the glacier surface and crevasse pattern during the 20year-period. Subglacial topography of Erikbreen was mapped in 1991 by radio-echo soundings (Ødegård et al. 1992). By combining these two information sources a Digital Elevation Model (DEM) of the glacier body was established for
1970 and 1990. Total net mass balance over the period 1970 to 1990 was calculated from the spatial change of surface altitude. The glacier flow pattern was evaluated from the changes in the surface slope and the crevasse pattern, and ice deformation velocities were calculated for both years. Mass balance data and calculated deformation velocities were compared with field measurements.

\section{Setting}

Erikbreen has an area of $9 \mathrm{~km}^{2}$ and an average depth of $140 \mathrm{~m}$. The maximum measured depth is $270 \mathrm{~m}$, which is found in the accumulation area (Ødegård et al. 1992). The surface is heavily crevassed. Erikbreen has a large accumulation area which is drained through a narrow and steep channel. This causes high surface velocities in the ablation area. The measured maximum velocity of $45 \mathrm{~m} / \mathrm{a}$ was determined downglacier from the equilibrium line altitude. At the glacier front the velocity was $20 \mathrm{~m} / \mathrm{a}$. Erikbreen has a thermal structure of two layers, with an upper cold layer 


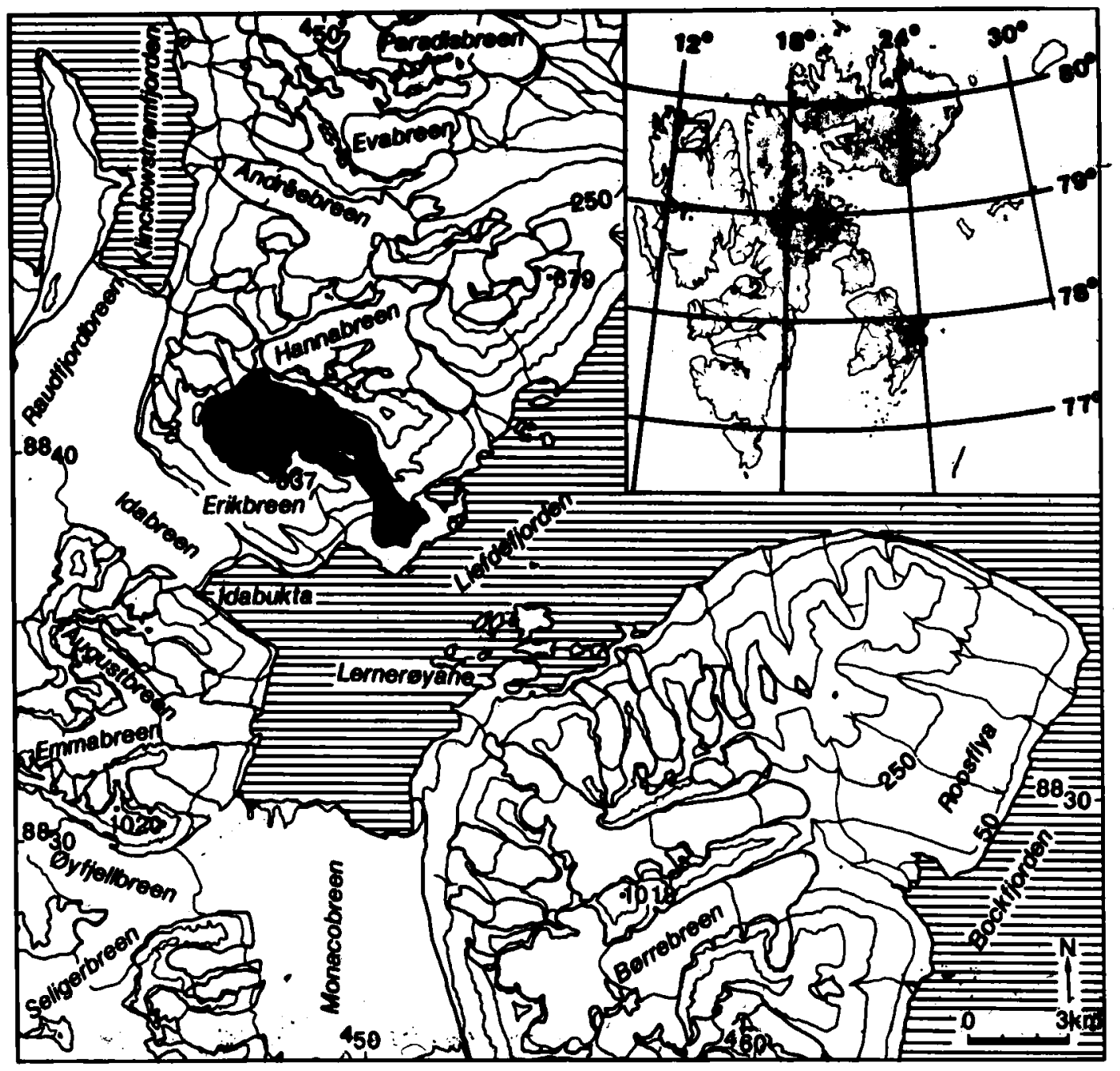

Fig. 1. The Liefdefjorden area, northern Spitsbergen. (1) Ny-Ålsund; (2) Longyearbyen.

and a temperate layer at the sole. The thickness of the cold surface layer was approximately $20 \%-$ $50 \%$ of the glacier thickness measured at the centre flow line ( $\varnothing$ degard et al. 1992). The mass balance of Erikbreen was positive in the balance year 1990/91, the equilibrium line being at $340 \mathrm{~m}$ a.s.l. (Etzelmüller et al. 1993). Between the present glacier front and an arc of ice-cored moraines, a lake was dammed at a level of $10 \mathrm{~m}$ a.s.l. (in 1992). The depth of this lake varied between $10 \mathrm{~m}$ and $36 \mathrm{~m}$ (in 1990), being deepest near the glacier terminus.

The nearest weather station is located in $\mathrm{Ny}$ Ålesund, approximately $80 \mathrm{~km}$ south of Liefdefjorden (Fig. 1), where a mean air temperature of $-6.2^{\circ} \mathrm{C}$ and a mean annual precipitation of $372 \mathrm{~mm}$ has been recorded (Hanssen-Bauer et al. 1990). Spitsbergen has continuous permafrost to $400 \mathrm{~m}$ depth (Liestøl 1977).

\section{Methods, error estimation and modelling}

\section{Work scheme}

This study consists of three main steps (Fig. 2): (1) Field surveying and photogrammetric work the digitizing of base topographic maps and crevasse pattern maps of Erikbreen from 1970 and 


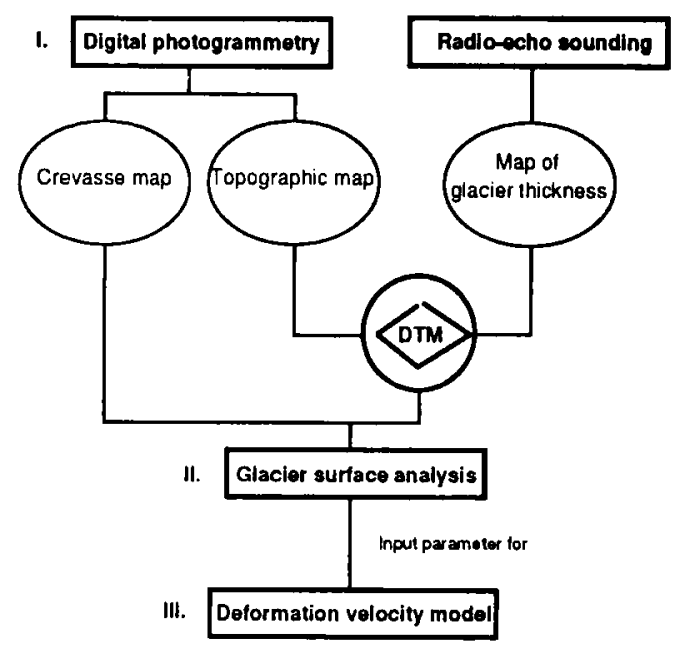

Fig. 2. Work scheme for this study based on digital photogrammetry and radio-echo sounding. The three basis maps are the crevasse pattern map, the topographic map and the interpolated map of glacier thickness (I). Based on these maps, glacier surface analyses were performed (II), which partly resulted in input parameters for an ice deformation velocity model (III). DTM = Digital Terrain Model.

1990; (2) Analysis of topographic maps and crevasse pattern - the analysis of changes in surface altitude, slope and crevasse pattern; (3) Calculation of basal shear stress and ice deformation velocity - the evaluation of changes in glacier flow.

\section{The base map - construction and errors}

Construction of the maps was carried out using a stereo plotter (WILD A7) equipped with digital encoders. On the stereospecific model S90-6566, the standard deviation of accuracy was computed from field measured signal points and prominent points in the moraine area (Table 1). Aerial tri- angulation was used for absolute orienting of neighbouring stereospecific models and the 1970air-photographs-series. Therefore, mean errors were markedly higher than for the first 1990 model pair (Table 1), but accuracy of less than one metre was usually achieved in all axial directions. Fivemetre contour lines could be digitized from the glacier surface (Fig. 3) at this level of accuracy. However, parts of the accumulation areas on the S90-series could not be constructed because of snow fall just before photographing (covering ca. $30 \%$ of the glacier area) which made contouring impossible.

The resulting topographic maps were converted in a Triangle Irregular Network (TIN) for 1 alief representation (cf. Burrough 1986) and transferred into a high resolution grid with a five-metre cell size. The accuracy of the S90 derived DEM was tested by comparing DEM-derived altitudes, with actual values measured in the field two days before air photographing. Different mean errors were obtained for the ablation and accumulation area because of fresh snow over part of the accumulation area and shadow effects in the infrared pictures. In parts of the ablation area (below $310 \mathrm{~m}$ a.s.l.) a mean error of less than $1.2 \mathrm{~m}$ was obtained (number of points $=25$ ), increasing to $3 \mathrm{~m}$ in the areas above $350 \mathrm{~m}$ (number of points = 6).

\section{GIS analysis}

Glacier surface analysis. - The basic information for the GIS analysis consisted of the two rasterbased altitude grids from 1970 and 1990 and the digitized radio-echo profiles. The raster-GIS module GRID in the software package ARC/ INFO (C) ESRI) was used for digital analysis. The GRID-system is based on Dana Tomlin's (1990) conceptional syntax and allows arithmetic, focal and zonal combinations between grids on a

Table 1 . Accuracy of registration from air photos. Mean errors are in metres.

\begin{tabular}{llllllll}
\hline Model & $\begin{array}{l}\text { Model } \\
\text { Nr. (1) }\end{array}$ & $\begin{array}{l}\text { Model } \\
\text { Nr. (2) }\end{array}$ & $\begin{array}{l}\text { No. } \\
\text { GCP's }\end{array}$ & $S_{x}$ & $S_{\mathbf{y}}$ & $S_{z}$ & $\mathbf{m}_{0}$ \\
\hline S90 & 6566 & 6565 & 7 & 0.304 & 0.050 & 0.020 & 0.195 \\
S90 & 6565 & 6564 & 7 & 1.270 & 0.743 & 1.779 & 1.295 \\
S70 & 2296 & 2297 & 12 & 0.713 & 1.270 & 0.397 & 0.885 \\
S70 & 2297 & 2298 & 7 & 0.807 & 0.820 & 0.653 & 0.771 \\
S70 & 2298 & 2299 & 9 & 0.414 & 0.401 & 0.589 & 0.469 \\
S70 & 2334 & 2333 & 8 & 0.641 & 0.668 & 0.390 & 0.600 \\
S70 & 2333 & 2332 & 7 & 1.002 & 0.849 & 0.730 & 0.879 \\
\hline
\end{tabular}




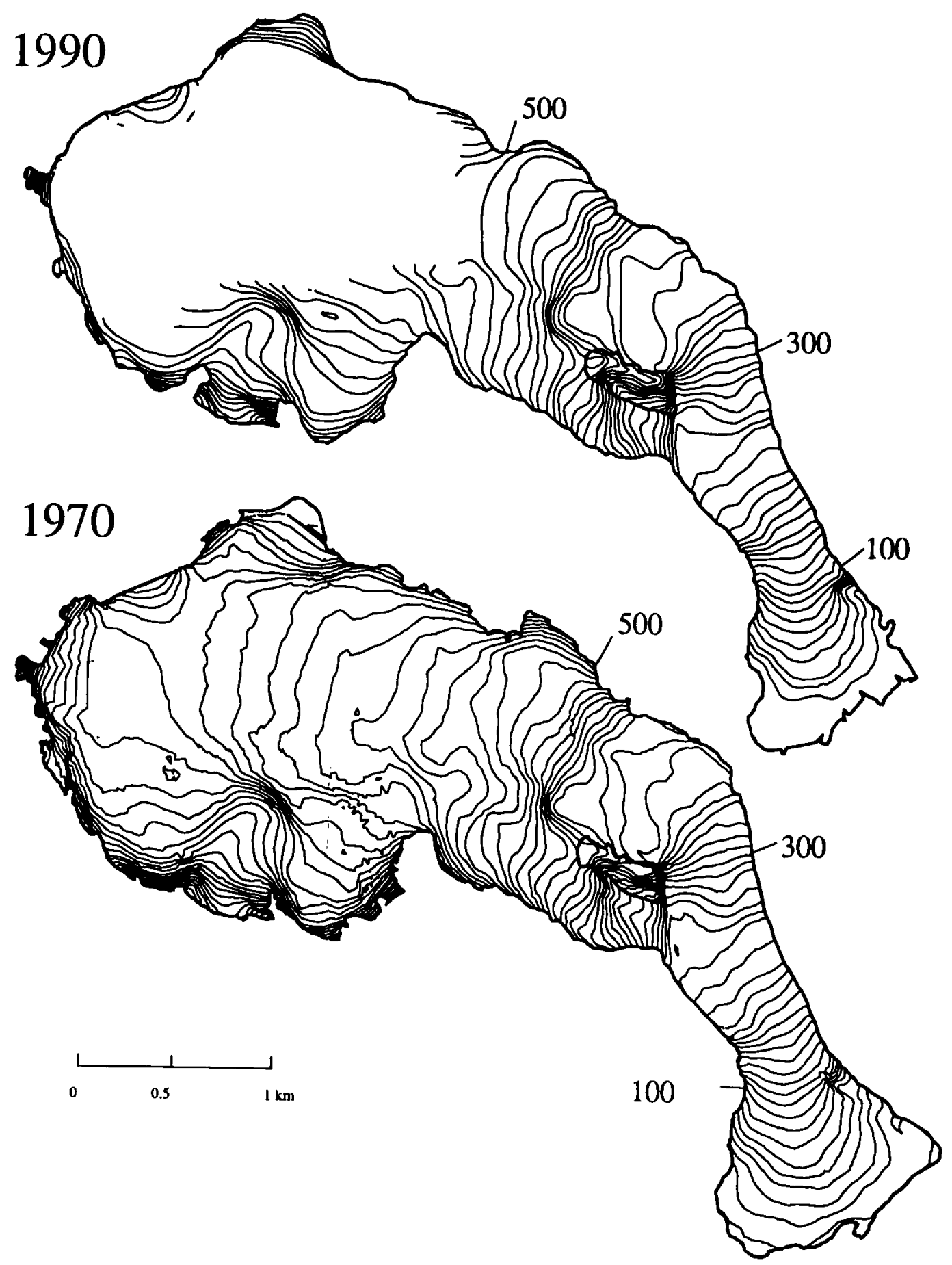

Fig. 3. Topographic surface maps of Erikbreen from 1970 and 1990. Parts of the accumulation area were not mapped in 1990 due to snow fall just prior to air photographing. 
cell by cell basis. The noise in the altitude grids was removed by a mean filter with $50 \mathrm{~m}$ kernel width.

The average volume change $\left(\Delta V_{j}\right)$ for a given elevation interval, $j$, of the glacier in $\mathrm{m}^{3}$ of ice and the average net balance $\left(b_{n j}\right)$ in metres of water was determined as:

$$
\begin{gathered}
\Delta V_{j}=d^{2} \times \sum_{i=1}^{n}\left(H_{1970}-H_{1990}\right) \\
\overline{b_{n j}}=\frac{\Delta V_{j}}{\Delta A_{j}} \times \frac{\rho_{\text {ice }}}{\rho_{w}}
\end{gathered}
$$

where $H$ is the surface altitude in $m$ (in years 1970 and 1990), $d$ is the cell resolution in metres, $\Delta A_{\mathrm{j}}$ is the glacier surface area in the elevation $j, \rho_{\text {ice }}$ is the ice density in $\mathrm{kg} \mathrm{m}^{-3}, \rho_{w}$ is the density of water $\left(1000 \mathrm{~kg} \mathrm{~m}^{-3}\right)$ and $n$ is the total number of cells for a given elevation interval. The ice-density was set to $\rho_{\text {ice }}=900 \mathrm{~kg} \mathrm{~m}^{-3}$ for the whole glacier. The change of the equilibrium line altitude during the study period has been neglected. The net balance $(V)$ of the whole glacier was obtained as

$$
V=\sum_{j=1}^{m} \frac{\rho_{\mathrm{ice}}}{\rho_{w}} \Delta V_{j}
$$

where $m$ is the total number of elevation intervals on the glacier (given as $\mathrm{m}^{3}$ of water)

Based on the altitude grids the glacier surface slope $(G)$ was calculated,

$$
\tan G=\sqrt{\left(\frac{\delta Z}{\delta X}\right)^{2}+\left(\frac{\delta Z}{\delta Y}\right)^{2}}
$$

where $Z$ is the surface altitude and $X$ and $Y$ are the coordinate axes in the horizontal plane (cf. Burrough 1986; Skidmore 1989; Zevenbergen \& Thorne 1987). The change of slope $(\Delta G)$ between $1970\left(G_{1970}\right)$ and $1990\left(G_{1990}\right)$ was computed as:

$$
\Delta G=G_{1970}-G_{1990}
$$

The dependence of surface lowering upon surface altitude and slope angle was analysed by applying zonal statistics in altitude or slope intervals. Graphs used in the text are automatically sampled from grids along pre-defined profile lines.

Crevasse pattern analysis. - The crevasse pattern was analysed by using the vector-based part of the ARC/INFO software pa ige. Crevasses were digitized as lines which start and end with a pseudo-node. Crevasse directions (in degrees clockwise from north) were calculated by using the coordinates of the nodes, which define the lines. The direction of the crevasses was therefore defined by a simple line although the crevasses in reality were curved. The lengths of single crevasses were not taken into consideration in the calculations.

Mean direction $(\theta)$, resultant $R$ and standardized resultant $R_{n}$ ( $R$ divided by number of observations $n$ ) were computed applying the following equations (Mardia 1972):

$$
\begin{gathered}
\bar{\theta}=\arctan \left(\frac{\sum_{i=1}^{n} \sin \theta_{i}}{\sum_{i=1}^{n} \cos \theta_{i}}\right) \\
R=\sqrt{\left(\sum_{i=1}^{n} \cos \theta_{i}\right)^{2}+\left(\sum_{i=1}^{n} \sin \theta_{i}\right)^{2}}
\end{gathered}
$$

To test differences in mean direction and the concentration parameter $k$ of two subsamples, Ftests (Mardia 1972) were applied on each subsample pair from 1970 and 1990.

Calculation of shear stress and ice deformation velocity. - The basal shear stress and the ice deformation velocity for parts of the glacier area were calculated using the GRID system. The basal shear stress and internal ice deformation velocity was computed from the surface slope and depth of a glacier, using Nye's (1952) model:

$$
u_{d}=u_{s}-u_{b}=\frac{2 A \tau_{b}^{n} h}{(n+1)}
$$

where $u_{\mathrm{d}}$ is ice deformation velocity, $u_{\mathrm{s}}$ and $u_{\mathrm{b}}$ are surface and basal velocities, respectively, $A$ and $n$ are constants from Glen's (1955) flow law for ice, $h$ is glacier thickness and $\tau_{b}$ is the basal shear stress:

$$
\tau_{b}=f \rho g h \sin \alpha
$$

where $f$ is a form factor (Nye 1965), $\rho$ is the density of the glacier, $g$ is the acceleration of gravity and $\alpha$ is the glacier surface slope. For Erikbreen, ice at the bed was assumed temperate (Ødegård et al. 1992). The constants of the flow law were set to $n=3$ and $A=1.67 \times 10^{-7}$ $a^{-1} \mathrm{kPa}^{-3}$ (Paterson 1981). The variable parameters were the glacier thickness $(h)$, the surface slope gradient $(\alpha)$ and the form factor $(f)$.

Glacier thickness interpolation was based on 


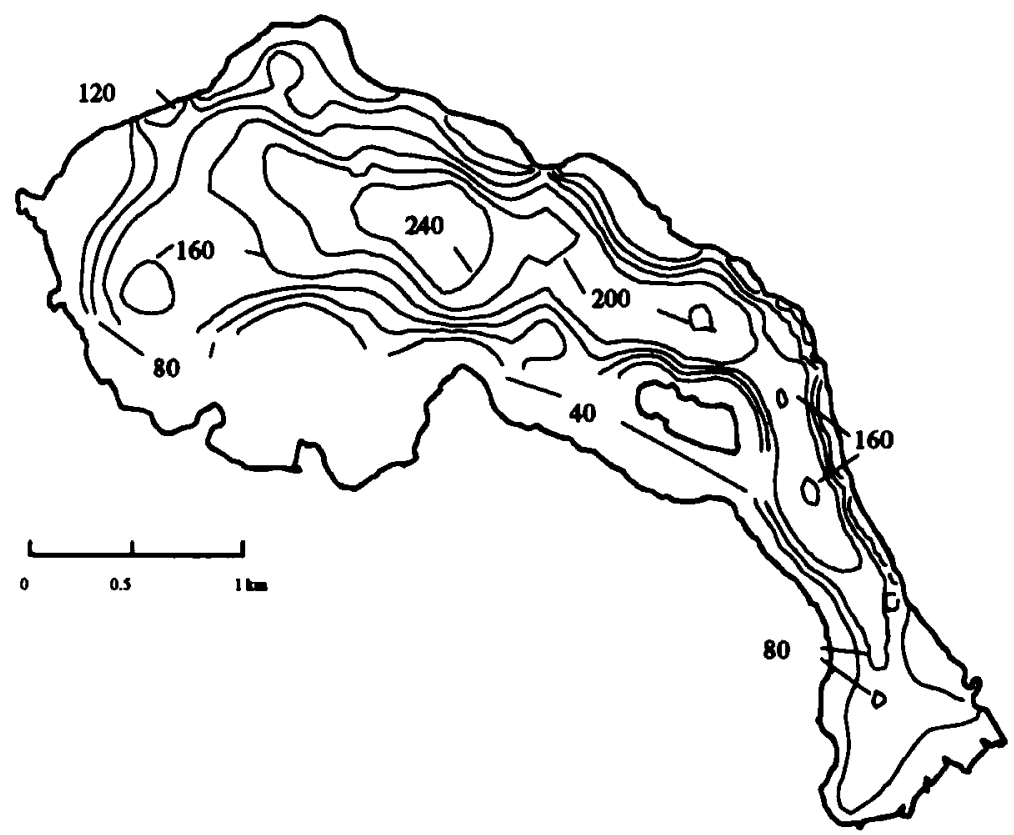

Fig. 4. Map of ice thickness. The equidistance of the contour lines is $40 \mathrm{~m}$. The map is interpolated by a third order inverse distance weighting based on radio-echo-sounding (Ødegård et al. 1992).

digitized radio-echo profiles ( $\varnothing$ degård et al. 1992 , fig. 4) and altitudes of the glacier's edge. The sounding lines were not significantly dense to make a good model of the subglacial topography, particularly in the ablation area. Estimates could, however, be made using data along the centre flow line of the glacier. A 50-m-cell-sized grid was computed representing glacier thickness in 1990. Glacier thickness in 1970 was computed by adding the computed altitude change to the glacier thickness data from 1990. A discussion of interpolation procedures of linear profile data is given elsewhere (Björnsson 1988; Herzfelt \& Holmlund 1988; Eriksen et al. 1993; Etzelmüller unpubl. data). A third order inverse distance weighting interpolation was used in calculations presented in this paper (Fig. 4).

When applying Nye's (1952) ice sheet model for ice-sheets and large valley glaciers (cf. Bindschadler et al. 1977; Paterson 1981), surface slope should be averaged over a surface length of 8 to 16 times the glacier depth. To compute slope averages on Erikbreen, low pass filtering techniques were used on the slope map, following the general equation

$$
r(i, j)=\sum_{m=1}^{M} \sum_{n=1}^{N} \phi(m, n) t(m, n)
$$

where $\phi$ is the slope in a given cell, $t$ is a kernel with size $M \times N$ and $r$ is the smoothed slope value. To avoid smoothing in all directions, window kernels taking the principle direction of the glacier channel into account (appr. $150^{\circ}$ clockwise from north) were applied on the slope grids. The kernel size could be varied between $300 \mathrm{~m}$ and $1000 \mathrm{~m}$ slope length averaging. A kernel which averaged slope over a surface length of $1000 \mathrm{~m}$ was used for calculations presented in this paper (Fig. 5).

The f-factor was derived for a parabolic channel cross-section from Nye's (1965) tables after calculation of the geometrical parameter $w=\frac{\text { width }}{2 \times \text { depth }}$. In the accumulation area the f-factor usually was 1 . A grid containing values of $w$ was calculated from a grid which contained information of zones with equal glacier width and the grid of glacier thickness. 


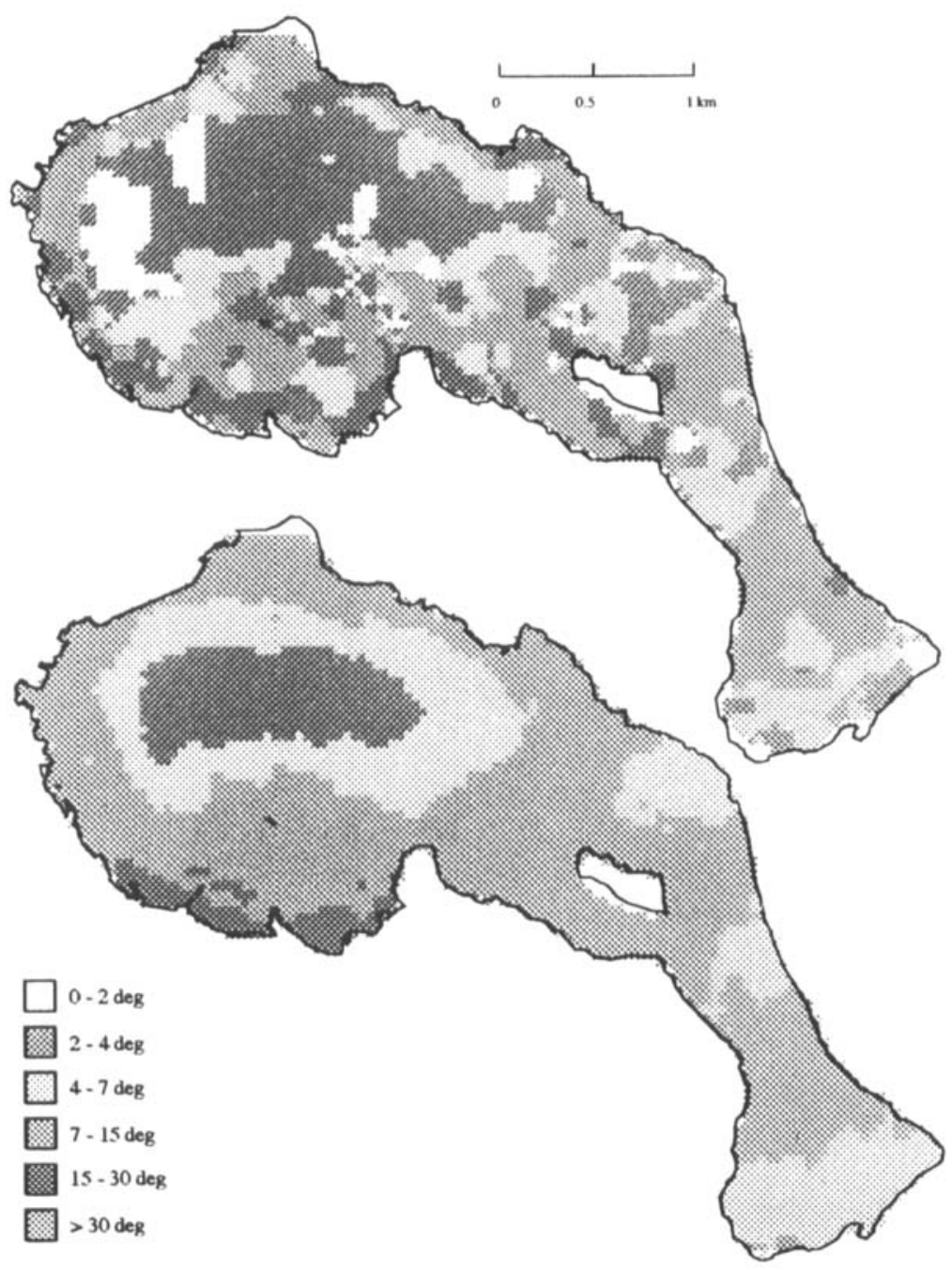

Fig. 5. Upper: Surface slope calculated from 1970 glacier. Lower: Smoothed surface slope from the 1970 glacier. The smoothing was carried out using a convolution kernel which smoothed the values over a distance of $1000 \mathrm{~m}$.

\section{Results}

Comparisons of the glacier surface in 1990 and 1970

The area of the glacier Erikbreen decreased by $8.1 \%\left(0.79 \mathrm{~km}^{2}\right)$ from 1970 to 1990 . Retreat at the glacier front accounted for $40 \%$ of this reduction.

As only $63 \%$ of the 1990 glacier surface could be mapped, calculations of changes in surface altitude over the whole glacier were not possible (Fig. 6). In the mapped area the mean surface altitude decreased by $11 \mathrm{~m}(0.55 \mathrm{~m} / \mathrm{a})$. The values ranged from over $35 \mathrm{~m}(>1.8 \mathrm{~m} / \mathrm{a})$ in the lower ablation area, to 5-15 $\mathrm{m}(0.3-0.7 \mathrm{~m} / \mathrm{a})$ at the equilibrium line area (Figs. 6, 7 and 8 ). In the area which lacks photogrammetric altitude data for 1990, a surface lowering of between 0 and $3 \mathrm{~m}$ was obtained by comparing geodetic measured surface altitude points along the centre flow line of the glacier with the 1970-altitude (number of points $=10$ ). In the retreat area of the glacier front a minimum average surface lowering of $14 \mathrm{~m}$ $(0.7 \mathrm{~m} / \mathrm{a})$ was obtained. Assuming an average surface altitude lowering of $1.5 \mathrm{~m}$ over the 20 - 


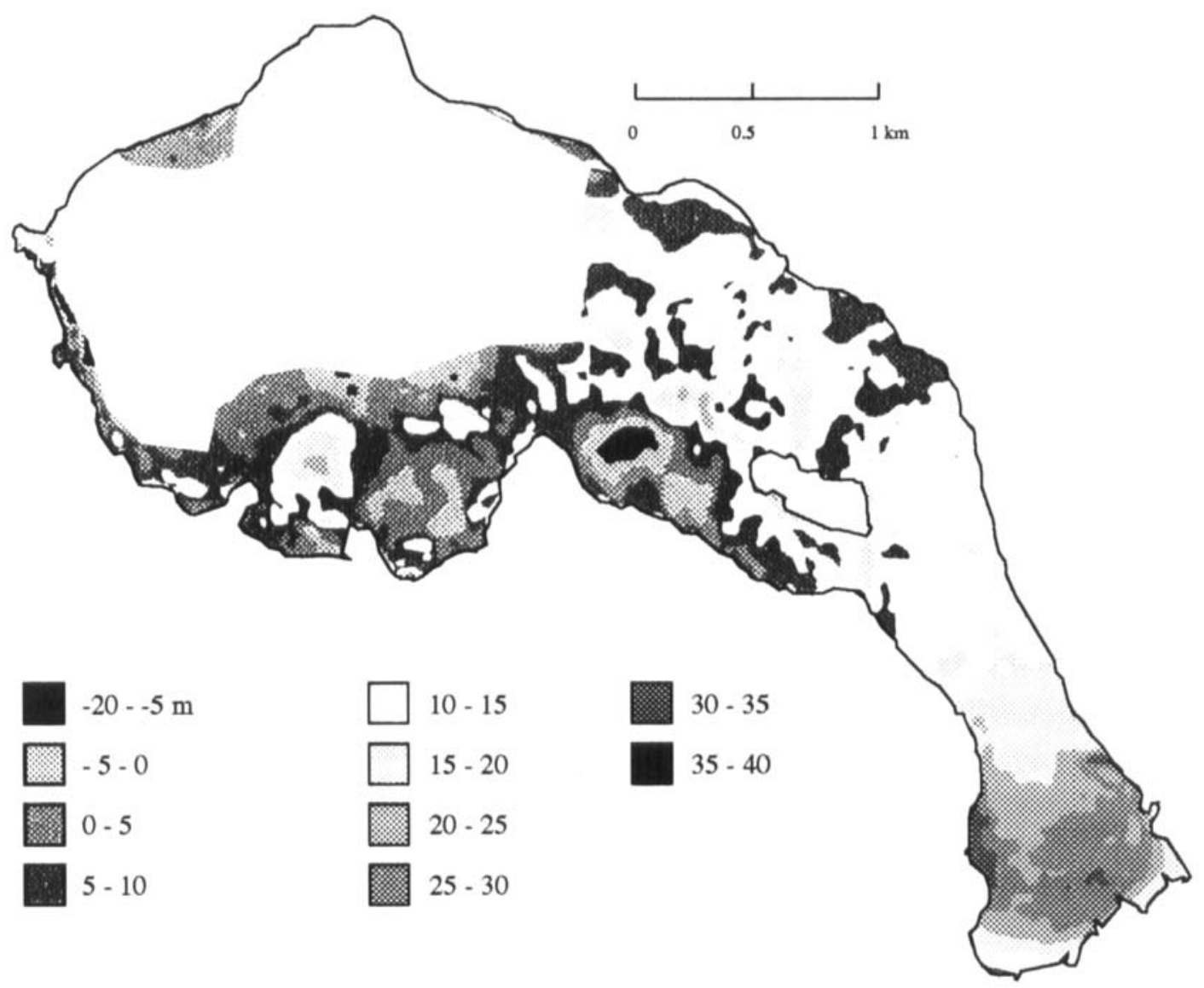

Fig. 6. Surface lowering of Erikbreen from 1970 to 1990.

year-period in a part of the accumulation area, where 1990 altitude data were not obtained, the average surface lowering over the whole glacier area was estimated as $7.5 \mathrm{~m}(0.38 \mathrm{~m} / \mathrm{a})$ between 1970 and 1990. However, smaller areas with minor net mass gain are situated on northfacing slopes in part of the accumulation area (Fig. 6). Assuming a mean glacier depth of $140 \mathrm{~m}$, the 1970 glacier volume was equivalent to approximately $1.25 \times 10^{9} \mathrm{~m}^{3}$ of water. Suggesting an altitude change of $0.5 \mathrm{~m} / 20 \mathrm{a}$ in the part of the accumulation area, where 1990 altitude data were not obtained, the volume of melted ice over the entire glacier was in the order of $6.5 \times 10^{7} \mathrm{~m}^{3}$ of water. For a suggested altitude change of $2.5 \mathrm{~m} / 20 \mathrm{a}$ in the same area the mass loss was calculated to $7 \times 10^{7} \mathrm{~m}^{3}$ of water. This represents a volume change of between $5 \%$ and $6 \%$ from 1970 to 1990. The annual mass loss therefore ranged from $3.2 \times 10^{6} \mathrm{~m}^{3} / \mathrm{a}$ to $3.5 \times 10^{6} \mathrm{~m}^{3} / \mathrm{a}$ of water. This gives an average annual specific discharge of $9 \mathrm{ls}^{-1} \mathrm{~km}^{-2}$ in the 20 -year period due to the mass loss.

A significant change in surface slope in the 20year period could only be traced in the lowermost ablation area (Fig. 9).

Crevasse pattern. - In the ablation area the number of crevasses on Erikbreen did not change significantly in the period of study (Figs. 10 and 11). Comparisons in the accumulation area were difficult to make due to fresh snow in 1990. Field observations, however, indicate a similar crevasse pattern as in 1970.

Rayleigh's test (Mardia 1972) of the standardized resultant (significance level $=\alpha_{0.1}$ ) indicates a preferred orientation of all samples. The crevasse pattern at the piedmont-like glacier front below $100 \mathrm{~m}$ a.s.l. showed a minor difference in mean direction (Fig. 11; Table 2), but statistically 


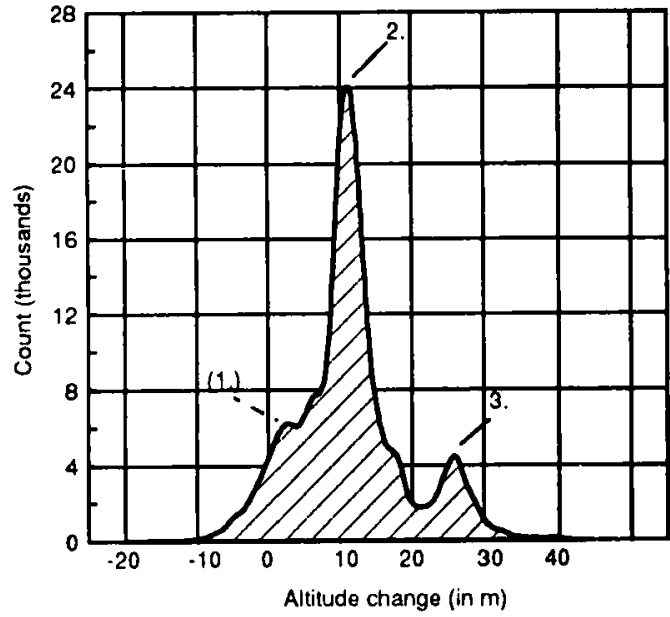

Fig. 7. Histogram of the surface lowering. The histogram shows a multimodal distribution, with three peaks. Using the histogram one can divide Erikbreen into at least three areas of similar appearance: The flat accumulation area between 500 and $600 \mathrm{~m}$ a.s.l. (altitude change $0-4 \mathrm{~m}$ ), the intermediate areas between 250 and $500 \mathrm{~m}$ a.s.l. (altitude change $8-15 \mathrm{~m}$ ), and the lowermost ablation area below $250 \mathrm{~m}$ a.s.l. (altitude change $>20 \mathrm{~m}$ ). Peak (1) represents altitude change in the accumulation area and would be higher if the whole glacier had been mapped. Peak (2) displays the average range of surface change in the ablation and lower accumulation area, while peak (3) represents the high surface changes in the lower ablation area.

significant differences in spread values $R$. The test on the concentration parameter $(\kappa)$ gave a significant change at significance level $=\alpha_{0.01}$ (Table 2). This area had a surface lowering of $>25 \%$ in relation to 1970 glacier depth along the centre flow line. In the area between 100 and $400 \mathrm{~m}$ a.s.l. the crevasse pattern is more uniform with $R_{\mathrm{n}}$-values of near 0.9 for both years.

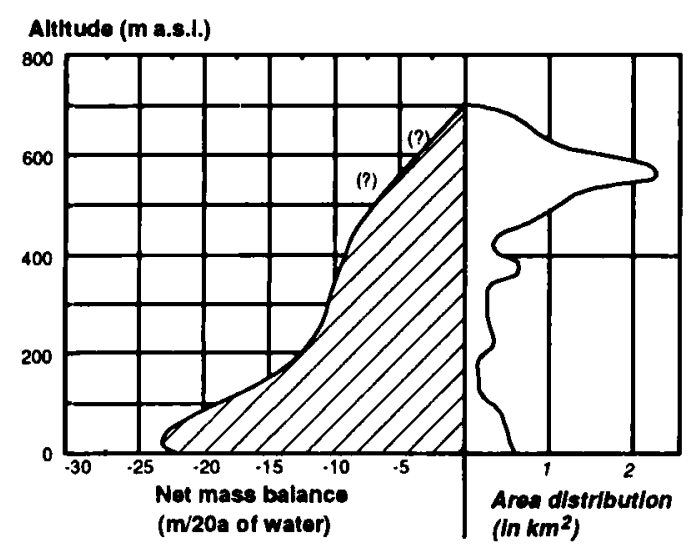

Fig. 8. Mass balance of Erikbreen in the period 1970-90.
However, testing on mean direction (Mardia 1972) at a significance-level $=\alpha_{0.5}$, gave F-values lower than the critical value. In the lower accumulation area no significant change in either direction or distribution was observed (Table 2).

\section{Estimated basal shear stress and deformation velocity}

Calculated basal shear stresses and ice deformation velocities in the centre flow line of Erikbreen ranged between $0.6-1.6 \mathrm{bar}$ and $1-40 \mathrm{~m} / \mathrm{a}$, respectively. Highest values were obtained at the glacier falls between stake 7 and stake 8 (Fig. 12).

The relative change of calculated ice deformation velocity during the 20 year period was calculated as the ratio $r=\frac{\nu_{1970}-\nu_{1990}}{\nu_{1970}}$. In the glacier area above $100 \mathrm{~m}$ a.s.l. $r$ oscillates between 0.2 and 0.3 , and $r$ increases below $100 \mathrm{~m}$ a.s.l. At the glacier terminus Nye's (1952) model is not applicable.

\section{Comparison with field measurements}

Mass balance. - On Erikbreen, mass balance measurements have been carried out during two balance years, 1990/91 and 1991/92. In the balance year 1990/91 the glacier had a weak positive mass balance $(0.14 \mathrm{~m})$ (Etzelmüller et al. 1992) while in 1991/92 the balance was zero to slightly negative. The average summer balance in the period 1990-92 ranged from $-2 \mathrm{~m} / \mathrm{a}$ in the ablation area to $-0.4 \mathrm{~m} / \mathrm{a}$ in the accumulation area (Table 3 ). The annual altitude decrease at Erikbreen in the period $1970-90$, at stakes positioned at the centre flow line of the glacier, was half or less of the average summer balance in 1990-92 (Table 3). If the average summer balance in 1990-92 was a reasonable estimate for the 20 year period, $50 \%$ of the surface lowering would have been compensated by ice flow in the ablation area.

Water balance. - The water balance of Erikbreen was measured during the summers from 1990 to 1992 (Vatne et al. 1992; Table 4). The monitoring program did not cover the entire melting season. Discharge measurements carried out on the south shore of Liefdefjorden in 1990, 1991 and 1992 for the period May/June to the end of August (Barsch et al. 1992) and in the river Bayelva (a meltwater river from Austre and Vestre Brøggerbreen 


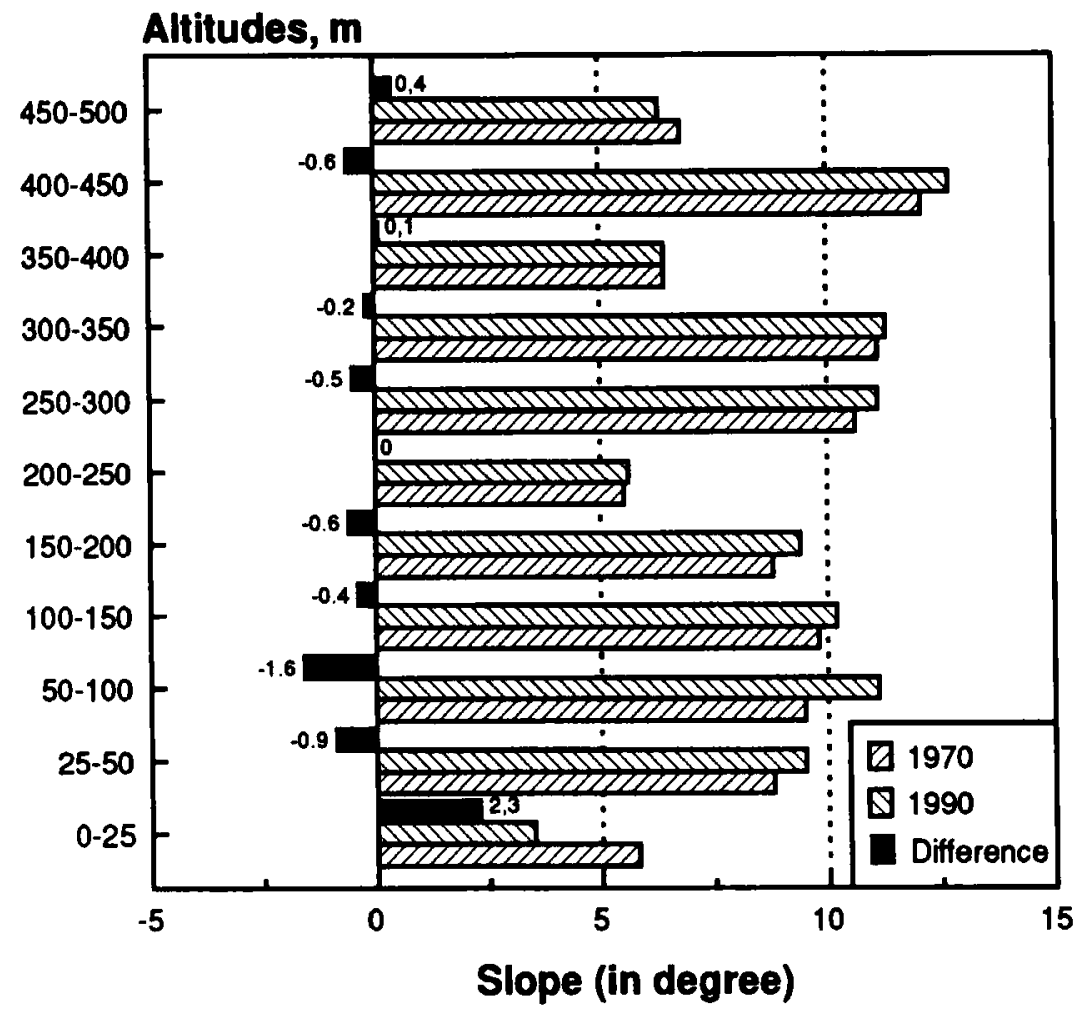

Fig. 9. Differences of slope in 1970 and 1990 in relation to altitude. The values are averaged over the altitude levels. Significant changes are only measured below $100 \mathrm{~m}$ a.s.l. where changes are $>10 \%$ change in relation to 1970 slope.

glacier) in the vicinity of $\mathrm{Ny}$-Ålesund (carried out by Norges vassdrags- og energiverk, NVE) indicate that the specific meltwater discharge from Erikbreen was higher than measured in 1990 to
1992 by a factor of 1.5 (for 1991) to 2 (for 1990 and 1992). This gives a specific discharge estimate of $15-40 \mathrm{Is}^{-1} \mathrm{~km}^{-2}$ from Erikbreen in 1990 to 1992 (Table 4).

Table 2. Crevasse pattern analysis - statistical moments and tests. The Roman numerals refer to area codes used in Figs. 10 and 11.

\begin{tabular}{|c|c|c|c|c|c|c|}
\hline & \multicolumn{2}{|c|}{$\begin{array}{l}\text { Area I (below } \\
100 \mathrm{~m} \text { a.s.l.) }\end{array}$} & \multicolumn{2}{|c|}{$\begin{array}{l}\text { Area II (100- } \\
300 \mathrm{~m} \text { a.s.l.) }\end{array}$} & \multicolumn{2}{|c|}{$\begin{array}{l}\text { Area III ( } 300- \\
500 \mathrm{~m} \text { a.s.l.) }\end{array}$} \\
\hline & 1970 & 1990 & 1970 & 1990 & 1970 & 1990 \\
\hline$\phi$ & 145.3 & 154.0 & 71.6 & 61.1 & 47.6 & 43.2 \\
\hline $\mathbf{R}_{\mathrm{n}}$ & 0.74 & 0.90 & 0.91 & 0.90 & 0.85 & 0.86 \\
\hline$\kappa$ & 2.289 & 5.305 & 5.852 & 5.305 & 3.68 & 3.91 \\
\hline $\begin{array}{l}\text { Two sample } \\
\text { tests (on } \phi \text { ) }\end{array}$ & \multicolumn{2}{|c|}{$\begin{array}{l}F_{1, n-2}=0.43 \\
\alpha_{0.1}=2.71\end{array}$} & \multicolumn{2}{|c|}{$\begin{array}{l}F_{1, n-2}=3.15 \\
\alpha_{0.1}=2.71 \\
\alpha_{0,05}=3.84\end{array}$} & \multicolumn{2}{|c|}{$\begin{array}{l}F_{1, n-2}=0.53 \\
\alpha_{0.1}=2.71\end{array}$} \\
\hline $\begin{array}{l}\text { Two sample } \\
\text { tests (on } \kappa \text { ) }\end{array}$ & \multicolumn{2}{|c|}{$\begin{array}{l}F_{n 1-1, n 2-1}=2.03 \\
\alpha_{0.01}=1.86\end{array}$} & \multicolumn{2}{|c|}{$\begin{array}{l}F_{n 1-1, n 2-1}=0.96 \\
\alpha_{0.03}=1.46\end{array}$} & \multicolumn{2}{|c|}{$\begin{array}{l}F_{n 1 \cdot 1 . n 2-1}=1.07 \\
\alpha_{0.15}=1.46\end{array}$} \\
\hline
\end{tabular}




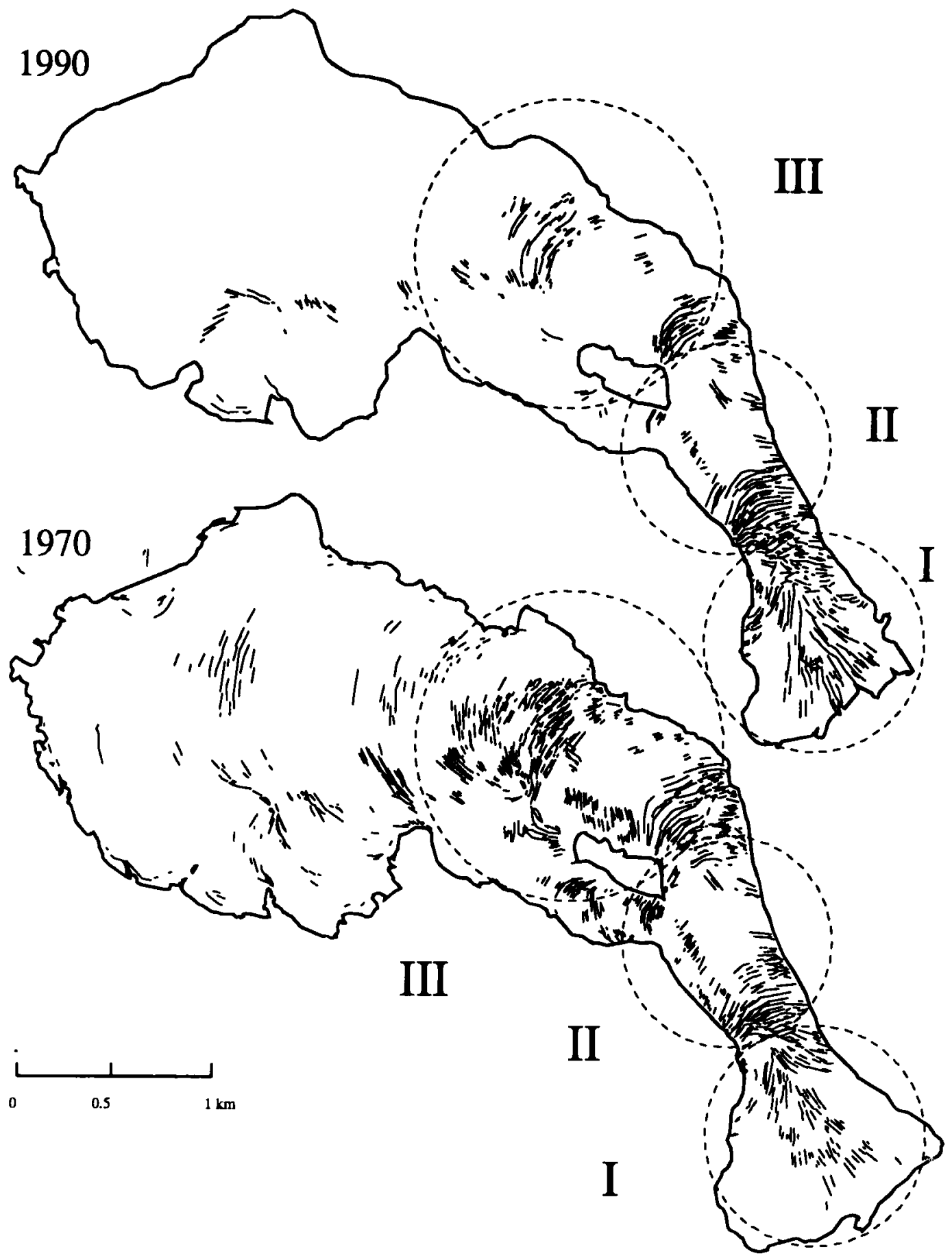

Fig. 10. Crevasse pattern of Erikbreen in 1970 and 1990. The Roman numerals refer to area codes used in Fig. 11 and Table 2. 


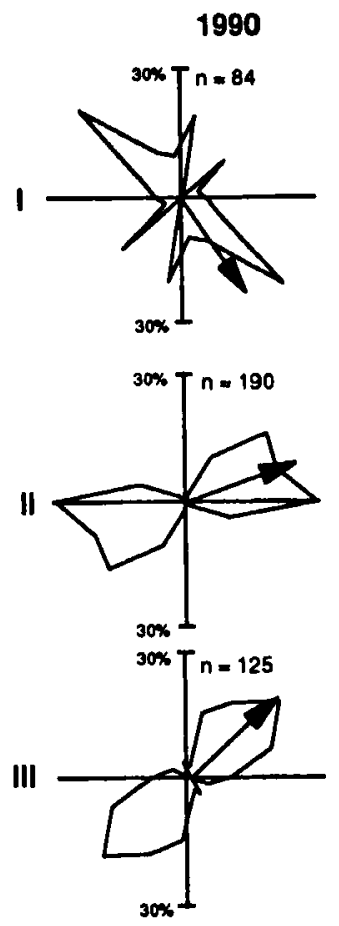

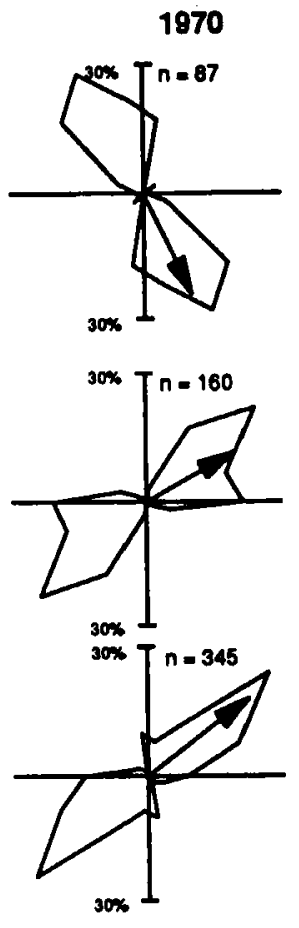

Fig. 11. Crevasse direction roses for Erikbreen in 1970 and 1990. The arrows indicate the principle mean direction of the crevasses, $n$ denotes the number of crevasses used in the analysis. The lower crevasse density measured north and west of the nunatak is due to snowfall covering crevasses in 1990.
Surface velocity. - Surface velocities on Erikbreen were measured in 1990, 1991 and 1992 at 10 stakes along the centre flow line of the glacier (Etzelmüller et al. 1993). The measured velocities were partly much higher than the calculated deformation velocities, indicating an increase of the basal sliding component downglacier (Fig. 12).

\section{Discussion}

\section{Total mass balance}

The surface altitude change data showed that Erikbreen had an average decrease of $7.5 \mathrm{~m}$ $(38 \mathrm{~cm} / \mathrm{a})$ for the last 20 years. This is in good accordance with data from Austre Brøggerbreen and Midre Lovénbreen in the vicinity of $\mathrm{Ny}$ Ålesund. Surface lowering of $8.9 \mathrm{~m}(42 \mathrm{~cm} / \mathrm{a})$ on Austre Brøggerbreen and $7.5 \mathrm{~m}(36 \mathrm{~cm} / \mathrm{a})$ on Midre Lovénbreen was calculated for the period 1967 to 1988, based on annual mass balance measurements (Hagen \& Liestøl 1990). Like other glaciers on Spitsbergen (Hagen \& Liestøl 1990), Erikbreen was not in climatic equilibrium, and due to the volume reduction water drained from the glacier in excess to that of an equilibrium state. Discharge measurements for Erikbreen

Table 3. Measured net and summer balance at stake 1 to 10 . All values are water equivalent. Summer balance consists of mean values from the period 1990-1992

\begin{tabular}{lllc}
\hline $\begin{array}{l}\text { No. } \\
\text { (m a.s. } . \text {.) }\end{array}$ & $\begin{array}{l}\text { Net balance } \\
(\mathrm{m} / \mathrm{a})\end{array}$ & $\begin{array}{l}\text { Summer balance } \\
(\mathrm{m} / \mathrm{a})\end{array}$ & $\begin{array}{l}\text { Mean altitude } \\
\text { change 1970-90 } \\
(\mathrm{m} / \mathrm{a})\end{array}$ \\
\hline $1(17)$ & $-1.16(90 / 91)$ & -2.04 & -1.1 \\
$2(14)$ & $-1.39(90 / 91)$ & -1.94 & -1.2 \\
$3(68)$ & $-1.83(90 / 91)$ & -1.67 & -1.1 \\
$4(133)$ & $-1.00(90 / 91)$ & -1.69 & -0.8 \\
$5(203)$ & $-0.37(90 / 91)$ & -1.22 & -0.6 \\
$6(311)$ & $-0.70(91 / 92)$ & -1.17 & -0.5 \\
$7(370)$ & $-0.12(90 / 91)$ & -1.08 & -0.6 \\
$8(487)$ & $-0.46(91 / 92)$ & & -0.6 \\
$9(536)$ & $+0.05(90 / 91)$ & -0.73 & $-\approx 0.1$ \\
$10(598)$ & $+0.03(91 / 92)$ & -0.48 & $-\approx 0.2$ \\
& $+0.55(90 / 91)$ & & \\
\hline
\end{tabular}



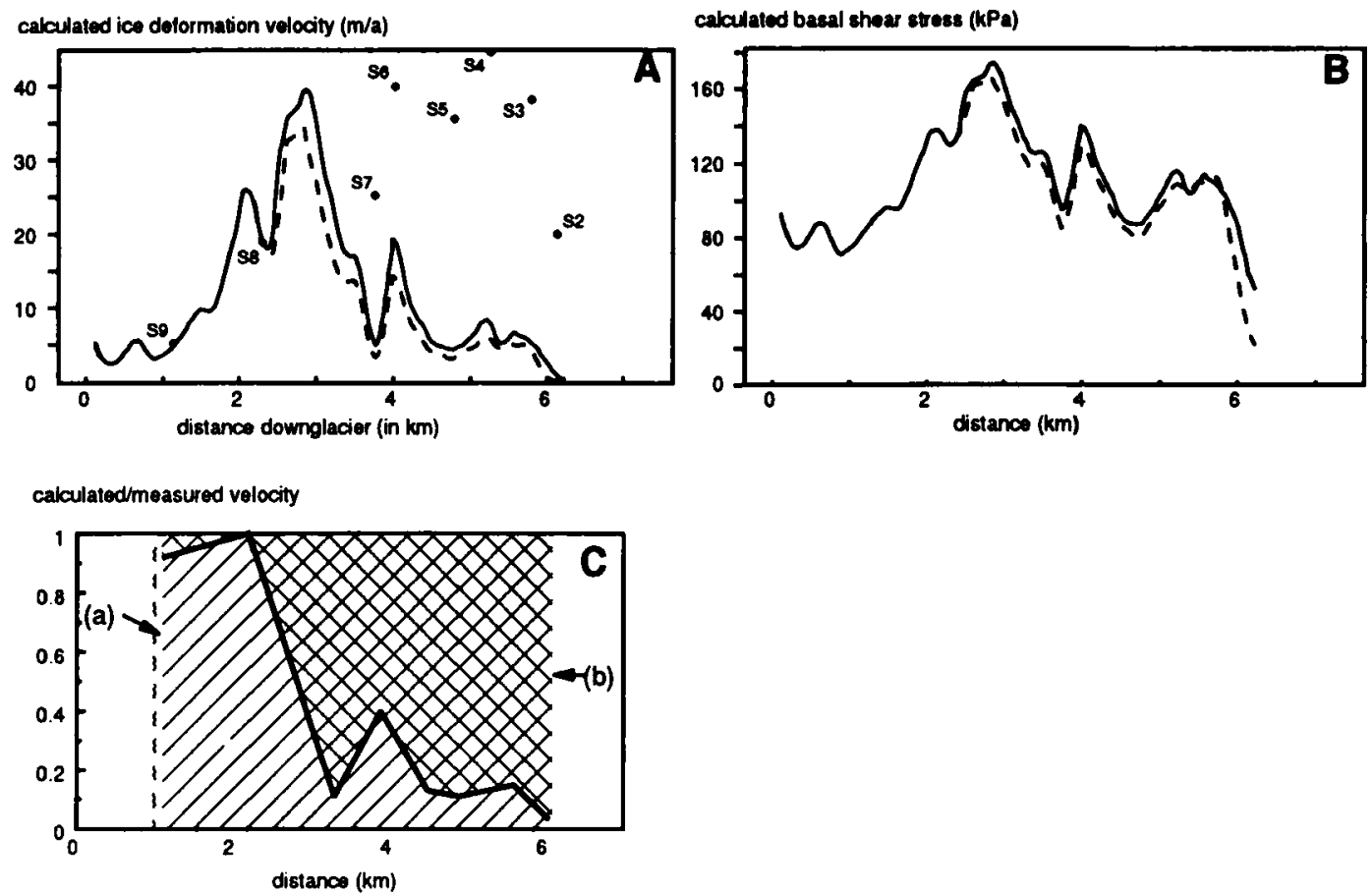

Fig. 12. Results of the calculation of ice deformation velocity. All data displayed in the graphs are sampled along the centre flow line of Erikbreen. A. Calculated ice deformation velocity. The dots denote measured surface velocity at the centre flow line of the glacier (in $\mathrm{m} / \mathrm{a}$ ). B. Calculated basal shear stress (in $\mathrm{kPa}$ ). Solid line represents the 1970 glacier; dashed line represents the 1990 glacier. These values are computed for a parabolic cross profile and slope averaging over $1000 \mathrm{~m}$. C. Ratio calculated/ measured velocity. The line-shaded area (a) indicates the deformation component of the measured surface velocity, while the cross-shaded area (b) indicates the basal sliding component. In the accumulation area the ratio is near 1 , decreasing to below 0.2 in the lowermost ablation area. This shows increased basal sliding downglacier.

indicated that specific runoff in a year with zero net mass balance was in the range $15-20 \mathrm{ls}^{-1} \mathrm{~km}^{-2}$ (Table 4). Water supplied from the reduction in volume of the glacier could be estimated in the range $2 \mathrm{ls}^{-1} \mathrm{~km}^{-2}$ to $20 \mathrm{ls}^{-1} \mathrm{~km}^{-2}$ or $10 \%-50 \%$ of the total runoff in 1992 and 1990 . In 1990 ablation was extremely high. These values seem comparable to data reported from Austre Brøggerbreen (Hagen \& Lefauconnier 1992) where the long-term runoff was estimated to be $30 \%$ higher than it would be under zero net balance conditions.

\section{Development of glacier flow}

An important question is how the thinning of Erikbreen affected the glacier flow. Liestøl (1969, $1988,1989)$ suggested that most of the Svalbard

Table 4. Discharge measurements on Erikbreen.

Specific discharge

(in $\mathbf{l s}^{-1} \mathrm{~km}^{-2}$ )

\begin{tabular}{|c|c|c|c|c|c|}
\hline \multirow[b]{2}{*}{ Year } & \multirow[b]{2}{*}{$\begin{array}{l}\text { Measurement } \\
\text { period }\end{array}$} & \multirow[b]{2}{*}{$\begin{array}{l}\text { Total } \\
\text { discharge } \\
\text { (in } 10^{6} \mathrm{~m}^{3} \text { ) }\end{array}$} & \\
\hline & & & $\begin{array}{l}\text { measurement } \\
\text { period }\end{array}$ & $\begin{array}{l}\text { over the } \\
\text { year }\end{array}$ & $\begin{array}{l}\text { estimated } \\
\text { total over } \\
\text { one year }\end{array}$ \\
\hline 1990 & 11 July-28 August & 8.3 & 169.0 & 21.3 & ca. 40 \\
\hline 1991 & 1 July-14 August & 3.4 & 83.6 & 10.1 & ca. 15 \\
\hline 1992 & 12 July-18 August & 4.4 & $118-0$ & 117.0 & ca. 22 \\
\hline
\end{tabular}


glaciers are of a surge type. Observations and measurements show that these glaciers are not able to maintain balance velocity at the equilibrium line altitude. This will result in a steeper surface profile as observed and described for Hessbreen, Finsterwalderbreen (Liestøl 1969), Usherbreen (Hagen 1987), Austre Brøggerbreen and Midre Lovénbreen (Hagen \& Liestøl 1990). The results presented here indicate that steepening of the glacier surface at the equilibrium line altitude is not the case for Erikbreen during the study period.

As the numbers of crevasses have not changed significantly over the 20 year period, it is assumed that the general flow pattern had not changed much.

In the area above $100 \mathrm{~m}$ a.s.l., basal shear stress was calculated to be $10 \%$ higher on average, and deformation velocity $20 \%-30 \%$ higher in 1970 than in 1990. The thinning of the glacier did not cause a significant increase of surface slope. Therefore, higher surface velocities could be expected in 1970 under the condition of unchanged thermal regime.

In the areas below $100 \mathrm{~m}$ a.s.l., where mass loss caused a more than $25 \%$ reduction of glacier thickness since 1970, surface slope increased and the crevasse pattern changed significantly. However, in the area below $25 \mathrm{~m}$ a.s.l. the glacier surface slope decreased. In the area between $25 \mathrm{~m}$ a.s.l. and $100 \mathrm{~m}$ a.s.l., computed shear stress and deformation velocity had not changed in relation to 1970 (Fig. 12). In the areas below $25 \mathrm{~m}$ a.s.l. shear stress and deformation velocity were assumed to be nearly zero in 1990 . However, in the same year high velocities of $20 \mathrm{~m} / \mathrm{a}$ were measured, which clearly showed the influence of buoyancy forces from the lake, inducing high sliding rates.

\section{The present glacier flow pattern}

The calculations and field measurements indicated that the present glacier flow pattern is dominated by an increasing basal sliding component downglacier in the ablation area of Erikbreen, which causes high surface velocities. Several explanations or combinations of these may be advocated: (a) subglacial drainage system and (b) deforming subglacial till.

(a) Erikbreen is highly crevassed in the ablation area. Hence, meltwater reaches the glacier bed at many locations. To collect these streams a high order dendritic system may be present as indicated by tracer studies carried out on Erikbreen in 1990 and 1991 (Vatne unpubl. data). As the melt rate is highest in the lower part of the ablation area, the meltwater would lubricate the bed most effectively in this area.

(b) Fine-grained till under Erikbreen has been observed in the glacier portal and the concentration and grain-size distribution of suspended sediments (Vatne et al. 1992) indicate that this layer extends some distance upglacier from the terminus. If subglacial till is present beneath parts of the glacier, it will be water saturated because of temperate conditions ( $\emptyset$ degård et al. 1992). During subglacial transport, clasts are comminuted, leading to reduction of the mean grain-size along the transport path (Dreimanis \& Vagners 1971). Therefore, the subglacial till may be most fine-grained in the lower ablation area. Fine-grained subglacial till will have low shear strength and be more easily deformable (Boulton et al. 1974; Boulton \& Hindmarsh 1987; Clarke 1987). Deforming subglacial till may therefore contribute substantially to the glacier flow velocity in the lower part of the glacier.

\section{Dynamic equilibrium}

Dynamic equilibrium means that the glacier maintains the balance velocity at the equilibrium line altitude. Rough estimations published in Etzelmüller et al. (1993) indicate that Erikbreen maintained balance velocity during 1990/91. Based on the following observations it was concluded that Erikbreen did not develop a dynamically unstable length profile from 1970 to 1990:

1. Surface lowering was observed in the accumulation area.

2. The velocity pattern did not change significantly.

3. The surface slope had not changed significantly above $100 \mathrm{~m}$ a.s.l.

4. The apparent high basal sliding rates in the ablation area maintained a high ice flux downglacier.

\section{Digital techniques}

Glaciological studies traditionally have used ana$\log$ terrestrial and air-photographically based photogrammetric measurements to map glacier surface changes (cf. Hoinkes 1970; Brunner \& Rentsch 1972; Finsterwalder \& Rentsch 1976; 
Finsterwalder 1978; Lipert 1987; Rentsch et al. 1990) and to measure glacier surface flow (cf. Finsterwalder 1931; Voigt 1966, 1967; Melvold 1992). With the recent development of powerful computer soft- and hardware, such data can be extracted and analysed digitally. This applies to DEM analysis of digital maps of a glacier body or differential surfaces and standardized analysis of glacier surface changes in time (cf. Peipe et al. 1978; Rentsch et al. 1990; Lundstrom et al. 1993). Additionally, derivates of the DEM analysis may be used to calculate glaciological variables, such as changes in ice deformation velocity or basal shear stress. Conventional GIS-software can be used in comparative studies of glaciers on a regional scale, concerning studies of the climatic impact on glacier mass balance and glacier dynamics. Changes in the glacier surface slope and the crevasse pattern have been used to explain changing dynamic behaviour of glaciers (Lefauconnier \& Hagen 1991). Using DEM, theoretical calculations of the subglacial drainage pattern are possible (cf. Bjørnsson 1988). Digital techniques, however, require knowledge of the accuracies of the sampled data. This is especially important when using interpolation procedures, particularly when not applying objective geostatistical methods as Kriging for interpolation (cf. Burrough 1986). However, the combination of DEMbased photogrammetric measurements and radioecho soundings integrated in a geographical information system (GIS) will become more important in the future for analysing glaciological data.

\section{Conclusions}

The mass balance of Erikbreen was negative during the period 1970 to 1990 . The same applies for other glaciers on Svalbard where long term mass balance measurements exist (Hagen \& Liestøl 1990; Lefauconnier \& Hagen 1990). Due to the mass loss of the glacier, the annual long-term runoff was at least $10 \%-20 \%$ higher than it would have been under equilibrium mass balance conditions. This effect might be decreasing as mass balance approaches zero on glaciers in Svalbard (Hagen \& Lefauconnier 1992).

In the area above $100 \mathrm{~m}$ a.s.l. the deformation velocity seems to have been reduced in the period of study. However, the thinning of the glacier did not cause a marked increase of glacier surface slope. In the glacier front zone, a moraine-dammed lake influenced glacier front dynamics, caus- ing high basal sliding velocities due to buoyancy forces. The crevasse pattern changed significantly only in areas below $100 \mathrm{~m}$ a.s.l. Measured surface velocities increased downglacier due to high basal sliding, which ensured high ice fluxes; thus Erikbreen did not develop an unstable surface profile in the period 1970-1990:

The combination of digital analysis of photogrammetric and radio-echo data provides a powerful tool for describing glaciers. The digital techniques can be carried out with commercial software, opening the potential for glacier surface analysis at a regional scale with the objectives of describing climatic dynamical changes of glaciers. The use of DEMs in glacier studies and modelling has been further emphasized by this study.

Acknowledgements. - The field work for the study of Erikbreen was carried out in connection with the German-led project "Stofftransporte Land-Meer in polaren Geosystemen" which was initiated by "Arbeitskreis für Polargeographie" and financially supported by the "Deutsche Forschungsgemeinschaft" (DFG). The project was coordinated by W. D. Blümel, University in Stuttgart. From the University of Oslo, O. Liestøl gave constructive advice for the study, I. Berthling. P. H. Вø and L. Langkaas took part in the field work and K. Melvold and $T$. Tonning did the photogrammetric mapping. Two anonymous reviewers improved the manuscript considerably.

The authors received financial support from the Deutsche Forschungsgemeinschaft (DFG), the Norwegian National Committee for Hydrology (NHK), the Norwegian Polar Institute and the Polar Committee of the Faculty of Science at the University of Oslo.

The authors would like to thank all persons and institutions mentioned above. All analysis presented in the paper were compiled at the Laboratory for Remote Sensing, Thematic Mapping and GIS at the Department of Geography, University of Oslo.

\section{References}

Barsch, D., Gude, M., Mäusbacher, R., Schukraft, G. \& Schulte, A. 1992: Untersuchungen zur aktuellen fluvialen Dynamik im Bereich des Liefdefjorden in NW-Spitsbergen. Stuttgarter Geographische Studien 117, 217-252.

Bindschalder, R., Harrison, W. D., Raymond, C. F. \& Crosson, R. 1977: Geometry and dynamics of a surge-type glacier. $J$. Glaciol. 18 (79), 181-194.

Björnsson, H., 1988: Hydrology of ice caps in volcanic regions. Societas Scientarium Islandica. University of Iceland. Reykjavik. $139 \mathrm{pp}$.

Boulton, G. S., Dent, D. L. \& Morris, E. M. 1974: Subglacial shearing and crushing, and the role of water pressures in tills from south-east Iceland. Geogr. Ann 56A (3-4), 135-145.

Boulton, G. S. \& Hindmarsh, R. C. A. 1987: Sediment deformation beneath glaciers; Rheology and geological consequences. J. Geophys. Res. 92, 9052-9082. 
Burrough, P. A. 1986: Principles of Geographical Information Systems for Land Resources Assessment. Monographs on Soils and Resources Survey No. 12, Clarendon Press, Oxford. $194 \mathrm{pp}$.

Brunner, K. \& Rentsch, H. 1972: Die Änderung von Fläche, Höhe und Volumen am Vernagt- und Guslarferner von 1889 1912-1938-1969. Z. Gletscherd und Glazialgeol. 8, 11-25.

Bø, P. H. 1992: Materialtransport i Midtdalsbreen, Sør-Noreg, og Vestre Lovénbreen og Erikbreen, Svalbard. Unpubl. Cand. scient. thesis, Department of Physical Geography, University of Oslo. $83 \mathrm{pp}$.

Clarke, G. K. C. 1987: Subglacial till: A physical framework for its properties and processes. Journal of Geophysical Research 92, 9023-9036.

Dreimanis, A. \& Vagner, J. J. 1971: Bimodal distribution of rock and mineral fragments in basal tills, Pp. 237-250 in Goldthwait (ed.): Till: a Symposium. Ohio State University Press.

Eriksen, M. G., Björnsson, H., Herzfeld, U. C. \& Holmlund, P. 1993: The bottom topography of Storglaciären. Naturgeografiska Institutionen, Forskningsrapport 95. 34 pp. + App.

Etzelmüller, B., Vatne, G., Ødegård, R. S. \& Sollid, J. L. 1993: Dynamics of two subpolar valley glaciers, Erikbreen and Hannabreen, Liefdefjorden, Northern Spitsbergen. Geogr. Ann. 75A (1-2), 41-54.

Finsterwalder, R. 1931: Geschwindigkeitsmessungen an Gletscher mittels Photogrammetrie. Z. Gletscherkd. Glazialgeol. 19, 251-262.

Finsterwalder, R. 1978: Beiträge zur Gepatschfernervermessung. Z. Gletscherkd. Glazialgeol. 14, 153-159.

Finsterwalder, R. \& Rentsch, H. 1976: Die Erfassung der Höhenänderung von Ostalpengletschern in den Zeiträumen 1950-1959-1969. Z. Gletscherkd. Glazialgeol. 12, 29-35.

Glen, J. W. 1955: The creep of polycrystalline ice. Proceedings Royal Society Series (London) A 238, 519-538.

Hagen, J. O. 1987: Glacier surge at Usherbreen, Svalbard. Polar Research 5, 239-252.

Hagen, J. O. \& Leistøl, O. 1990: Long term glacier massbalance investigations in Svalbard, 1950-88, Ann. Glaciol. 14, 102-106.

Hagen, J. O. \& Lefauconnier, B. 1992: Reconstructed runoff from the high Arctic basin Bayelva in Svalbard based on mass-balance measurements. Pp. $155-168$ in Prowse, C. S. I. \& Ulmer, K. E. (eds): Proceedings, 9th International Northern Research Basins Symposium/Workshop, Canada, NHRI Symposium No. 10.

Hanssen-Bauer, I., Kristensen Solås, M. \& Steffensen, E. L. 1990: The climate of Spitsbergen. The Norwegian Meteorological Institute, Report No. 39/90. 40 pp.

Herzfelt, U. C. \& Holmlund, P. 1988: Geostatistical analysis of radio-echo data from Scharffenbergbotnen, Dronning Maud Land, East Antarctica. Z. Gletscherkd. Glazialgeol. 24, 95110.

Hoinkes, H. 1970: Methoden und Möglichkeiten von Massenhaushaltsstudien auf Gletschern. Z. Gletscherkd. Glazialgeol. 6, 38-85.

Lefauconnier, B. \& Hagen, J. O. 1990: Glaciers and climate in Svalbard; statistical analysis and reconstruction of the Brøggerbreen mass-balance for the last 77 years. Ann. Glaciol. 14, 148-152.

Lefauconnier, B. \& Hagen, J. O. 1991: Surging and calving glaciers in eastern Svalbard. Norsk Polarinst. Medd. Nr. 116. 130 pp.

Leistøl, O., 1969: Glacier surges in West Spitsbergen. Can. J. Earth Sci. 6 (4), 895-897.

Liest 61, O. 1977: Pingos, springs and permafrost. Norsk Polarinst. Arbok 1975, 7-25.

Liestøl, O. 1988: The glaciers on the Kongsfjorden area. Norsk Geograf. Tidsskr. 42 (4), 231-238.

Liestøl, O. 1989: Kompendium i glasiologi. Meddelelser fra Geografisk institutt, Universitetet i Oslo. Naturgeografisk serie, Rapport nr. 15. Oslo. 87 pp.

Lipert, C. 1987: Photogrammetric works in the Werenskiold Glacier area, Spitsbergen. Polish Polar Res. 8, 47-55.

Lundstrom, S. C., McCafferty, A. E. \& Coe, J. A. 1993: Photogrammetric analysis of 1984-89 surface altitude change of the partially debris-covered Eliot Glacier, Mount Hood, Oregon, U.S.A. Ann. Glaciol. 17, 167-170.

Mardia, K. V. 1972: Statistics of directional data. Academic Press, London. 357 pp.

Melvold, K. 1992: Studie av brebevegelse på Kongsvegen og Kronebreen, Spitsbergen. Meddelelser fra Geografisk institutt, Universitetet i Oslo. Rapportserie $i$ naturgeografi, Rapport nr. I. $60 \mathrm{pp}+$ App.

Nye, J. F. 1952: The mechanics of glacier flow. J. Glaciol 2 (26), 82-93.

Nye, J. F. 1965: The fiow of a glacier in a channel of rectangular, elliptic or parabolic cross-section. J. Glaciol 5, 661-690.

Ødegård, R., Hamran, S. E., Bø, P. H., Etzelmüller, B., Vatne, G. \& Sollid, J. L. 1992: Thermal regime of a valley glacier, Erikbreen, northern Spitsbergen. Polar Res. 11 (2), 69-80.

Paterson, W. S. B. 1981: The Physics of glaciers. Pergamon Press. Oxford. $378 \mathrm{pp}$.

Peipe, J., Reiss, P. \& Rentsch, H. 1978: Zur Anwendung des digitalen Gelandemodells in der Gletscherforschung. $Z$. Gletscherkd. Glazialgeol. 14, 161-172.

Rensch, H., Welsch, W., Heipke, C. \& Miller, M. M. 1990: Digital terrain models as a tool for glacier studies. J. Glaciol. 36, 273-278.

Skidmore, A. K. 1989: A comparison of techniques for calculating gradient and aspect from a gridded digital elevation model. Internat. J. Geograph. Infor. Sys. 3 (4), 323-334.

Sollid, J. L., Etzelmüller, B., Vatnc, G. \& Ødegård, R. S. in press. Glacial dynamics, material transfer and sedimentation of Erikbreen and Hannabreen, Liefdefjorden, northern Spitsbergen. Zeitschrift für Geomorphologie, Suppl. Band.

Tomlin, Dana C. 1990. Geographic information systems and cartoraphic modeling. Prentice Hall, N.J. 246 pp.

Vatne, G., Etzelmüller, B., Ødegsard, R. \& Sollid, J. L., 1992: Water-budget and glaciofluvial sediment transfer of a subpolar glacier, Erikbreen, Svalbard. Stuttgarter Geographische Studien 117, 253-267.

Voigt, U. 1966: The determination of the direction of movement on glaciers surface by terrestrial photogrammetry. J. Glaciol. $6,359-367$.

Voigt, U. 1967: Ergebnisse der Bewegungsmessungen an Kongsvegen und Kronebreen. Geodätische und geographische Veröffentlichungen, Reihe III, Heft 9, 70-98. Berlin. Zevenbergen, L. W. \& Thorne, C. R. 1987: Quantitative analysis of land surface topography. Earth Surface Processes and Landforms 12, 47-56. 